\title{
The University of Chicago Law School: Ruminations and Reminiscences
}

\author{
Bernard D. Meltzer $\dagger$
}

I have, I believe, been given the privilege of writing for this centennial issue primarily because of my well-aged and affectionate ties to the University of Chicago Law School. In 1934, I became a firstyear student there and thus began a connection spanning more than two-thirds of the Law School's existence. My connection as a faculty member began in 1946; and, if I may count my days as an emeritus (beginning in 1985), I have been on the faculty for more than one-half of the school's existence.

Naturally, I have heard, repeated, and created a good deal of hearsay regarding the school, beginning with its founding. My memories of later events that I actually observed may, of course, have improved with age. Furthermore, they have undoubtedly been reshaped by hindsight. In any event, the core of much of what follows will be an old story to some of you. My working principle for birthday parties, and especially centennials, is nostalgia rather than novelty. Indeed, I am concerned that I may help validate Paul Freund's observation that nostalgia is not what it used to be.

I will say something about three topics: (1) the birth pangs of the Law School, (2) my student days, and (3) the post-World War II reinvigoration of the Law School that reflected and reinforced its original conception of a broad-gauged legal education. My stopping point will, in general, be 1962, when Edward Levi left the deanship of the Law School in order to become Provost of the University.

\section{THE EARLY YEARS ${ }^{1}$}

The University's first president, William Rainey Harper, had stressed from the beginning that a law school should be an integral

$\dagger$ Edward H. Levi Distinguished Service Professor Emeritus of Law, The University of Chicago. I am fortunate in having an unusually large number of individuals to thank for their contributions to this slender Essay: Dennis Hutchinson, Saul Levmore, Jo Desha Lucas, Daniel Meltzer, and Jean Meltzer, for their valuable comments on an earlier draft; Virginia Kim, Rhett Larson, and Martha Pacold, for most helpful research; Brian Sullivan and David Warrington, for materials from the Harvard Law School; and the staff of our own D'Angelo Law Library and of Special Collections at the University of Chicago Library, for their resourceful help.

1 For Part I, I have drawn on Frank L. Ellsworth, Law on the Midway: The Founding of the University of Chicago Law School (The Law School of the University of Chicago 1977); and Comment, Ernst Freund-Pioneer of Administrative Law, 29 U Chi L Rev 755, 763-70 (1962). 
part of the University. ${ }^{2}$ But he had to wait until the time was ripe and, particularly, until the money was there. In the planning stages he turned primarily to Ernst Freund, a lawyer trained in Germany and a member of the University's political science department, for advice; to John D. Rockefeller, for money; and to the Harvard Law School, for Chicago's first dean.

Chicago's general idea was to establish an institution comparable in quality to Harvard's distinguished law school. Harvard had a more specific idea. It viewed itself as Chicago's potential Godfather, responsible for seeing to it that the fledgling school would be faithful, at least initially, to Harvard's aims and methods.

Harper had worked out a tentative arrangement with Dean James Barr Ames (of the Harvard Law School) for Joseph Henry Beale, Harvard's Royall Professor of Law, to serve temporarily as Chicago's first dean, beginning in 1902. Accordingly, Harper dispatched Ernst Freund to Cambridge for a discussion of Freund's and Harper's ideas about Chicago's curriculum.

Freund, like Harper, had a broad conception of a legal curriculum. As electives, Freund would have included a wide range of courses that were not offered by Harvard. ${ }^{3}$ Apparently, Freund contemplated that some of these subjects might be "integrated" with conventional law courses and, that some might even be taught independently in a pre-professional year, for which the Law School would be responsible. Freund's general conception of what future lawyers should study went back to Jefferson and indeed to Blackstone. ${ }^{5}$

Ames and Beale, however, found Freund's views heretical. Ames, accordingly, wrote Harper along these lines: Ames understood that Harper had wished, and still wished, to establish a law school at Chicago "resembling as closely as possible in its curriculum, methods of study, and quality of its Faculty, the Harvard Law School." But Professor Freund's conception was fundamentally and disturbingly differ-

2 See Ellsworth, Law on the Midway at 29 (cited in note 1).

3 Freund's list included Administrative Law, Constitutional Law, Taxation, Accounting, International Law, Economics, Political Theory, Jurisprudence, Public Officers, Municipal Corporations, and Federal Practice. See id at 39.

4 See Herbert A. Johnson, Thomas Jefferson and Legal Education in Revolutionary America, in James Gilreath, ed, Thomas Jefferson and the Education of a Citizen 103, 112 (Library of Congress 1999) (describing Jefferson's attitude toward legal education as a form of "citizenship training"). See also id at 103-04, 107-08, 109.

5 See William Blackstone, 1 Commentaries on the Laws of England *33-34 (stating that the lawyer-to-be should be grounded in a broad-based liberal education before beginning the study of the practice of law).

6 Letter from James B. Ames, Dean of the Harvard Law School, to William R. Harper (Mar 31, 1902), reprinted in Comment, $29 \mathrm{U}$ Chi L Rev at 764 (cited in note 1) (emphasizing the differences between Freund's view of legal education and the Harvard approach). See also id at 766 n 40 (reproducing a letter of similar import from Beale to Harper). 
ent from Harvard's. First, Freund had suggested that two-ninths of the work leading to a law degree should consist of work properly belonging, in Ames's view, to political economy or sociology; Harvard's law curriculum had no such subjects, and the Harvard Law School itself was opposed to teaching anything but "pure law." Second, Freund, unlike Harvard, would admit nonlawyers to the law faculty to teach such subjects. Ames memorably added, "We believe the success of our School is due in no small degree to the solidarity of our Faculty and to its concentration upon the work of teaching the law pure and simple." Third, Freund's views and his belief in the general method of German universities appear to have predisposed him against "the systematic study of Cases," a method to which the Harvard Law School was committed.' Ames concluded by indicating that Beale's proposed leave of absence would not be in Harvard's interest unless Chicago's faculty consisted exclusively of lawyers who both believed in Harvard's methods and met Beale's approval.

Ames's views contrasted sharply with those expressed a few years earlier by Oliver Wendell Holmes in The Path of the Law, which was to become probably the most quoted legal address in our history. Holmes had said, "For the rational study of the law the black-letter man may be the man of the present, but the man of the future is the man of statistics and the master of economics." ${ }^{10}$ Holmes also expressed regret at the divorce between the schools of political economy and law." By contrast, Dean Ames had anticipated W.H. Auden's dictum:

Thou shalt not sit

With statisticians nor commit

A social science.

7 Id at 764

8 Id (emphasis added).

9 Id. Freund believed in the case method but also believed, as other teachers did, that its effectiveness declined after the first year. See Maurice T. Van Hecke, Comment, Ernst Freund, as a Teacher of Legislation, $1 \mathrm{U}$ Chi L Rev 92,93 (1933) ("As early as 1915 he was saying what was then heresy but has since become a slogan: that the effectiveness of the case method of legal instruction begins to decline about the middle of the student's second year."). I will pass over the variations in the use of "the case method." See Comment, $29 \mathrm{U}$ Chi L Rev at $768 \mathrm{n} 43$ (cited in note 1).

10 O.W. Holmes, The Path of the Law, 10 Harv L Rev 457, 469 (1897).

11 See id at 474 . For a discussion of the themes in Holmes's address, the tension among them, and their influence on legal education and adjudication, see the articles comprising The Path of the Law After One Hundred Years, 110 Harv L Rev 989-1054 (1997); Albert Alschuler, Law Without Values: The Life, Work, and Legacy of Justice Holmes ch 7 (Chicago 2000).

12 W.H. Auden, "Under Which Lyre: A Reactionary Tract for the Times," in W.H. Auden, Nones 64, 70 (Random House 1950). 
I have not found any response by Harper to Ames's demands. Both sides seem to have given ground. ${ }^{13}$ Thus, the University of Chicago Law School opened its doors on October 1, 1902, in temporary quarters in the Press building ${ }^{14}$-on the northwest corner of 58th and Ellis, at the site now occupied by the bookstore.

The original faculty was a stellar group. In addition to Beale and Freund, there were James Parker Hall, Blewett Lee, Julian W. Mack, Floyd R. Mechem, and Clarke B. Whittier. ${ }^{15}$ This roster was supplemented by an impressive group of lecturers.

The potential battle between Beale and Freund over their rival conceptions never materialized, and the Law School's first announcement of its purpose and curriculum surely bore Freund's and Harper's imprint. The school's statement of purpose gave top billing to professional training, but also recognized the school's aspiration to "cultivate and encourage the scientific study of systematic and comparative jurisprudence, legal history, and principles of legislation." ${ }^{16}$ In seeking to reach this objective, the early course offerings departed from the beaten path. The Announcements reflected the school's continuing interest in integrating law and related disciplines. ${ }^{17}$

The Law School's unique program and distinguished faculty led to an enrollment of seventy-six men and two women in the school's first year. ${ }^{18}$ The admission of women was, of course, another significant innovation. The following year, the number and the geographical diversity of the students in the professional program increased sharply. ${ }^{19}$ Chicago had quickly established itself as a national law school.

13 Beale's service as Chicago's temporary dean elicited high praise. Freund, in a convocation speech, praised Beale's contribution, the "freshness and vigor of [his] mind, and [his] love of sound law." Ellsworth, Law on the Midway at 75-76 (cited note 1) (emphasis added).

14 New Law School a Success, 1 The Daily Maroon No 1, 1 (Oct 1, 1902) (University of Chicago student newspaper) (describing the opening day, faculty, students, and facilities of the new Law School).

15 Mack and Lee were recruited from Northwestern; Mechem from Michigan; Hall and Whittier from Stanford. Ellsworth, Law on the Midway at 77 (cited in note 1). Ellsworth provides additional information about the background of the "First Faculty" and the negotiations leading to their recruitment, as well as failed efforts to recruit other luminaries. See id at 77-91.

16 The Law School, 2 Circular of Information: The University of Chicago No 4, 3 (June 2, 1902).

17 The names of the first-year courses were traditional. But the second- and third-year electives included such innovations as Constitutional Law I (Organization of government, Police power); Municipal Corporations; and the Elements of International Law (taught by Professor Hudson, a political scientist). See, for example, 2 Circular of Information at 7-8 (cited in note 16). Other significant innovations (deferred until the following year) included Administrative Law and Roman Law. See id.

18 The first set of students included an additional twenty pre-professional students who had completed two years of college and who were to take an extra year of work in the Law School. See Ellsworth, Law on the Midway at 125 (cited in note 1);2 Circular of Information at 3 (cited in note 16).

19 The enrollment rose from 78 to 126 , and the number of states represented more than 
The establishment of the Law School was a tribute to President Harper and Professor Freund, Mr. Rockefeller, and to Harvard's President Charles Eliot, Dean Ames, and Professor Beale. As President Eliot proudly observed, Harvard's help was a

striking instance of effective cooperation by two universities. The older university thus puts all its experience in carrying on a law school at the service of the younger university, and lends a valued professor to serve as organizer and temporary administrator of the new school. It is evident that the common commercial motives have not governed this transaction. ${ }^{20}$

Harvard's claim of noblesse oblige was wholly justified, but its view of what should be taught, and who was to be permitted to teach in a law school, was, of course, a different matter. As Professor Samuel Williston, writing in 1948, acknowledged (and sought to explain), Harvard had been "somewhat narrow and shortsighted in the nineties and in the early years of this century.",21

The question raised at our creation - the appropriate relationship between the study of law and of interdependent disciplines-became a central issue for legal education in the twentieth century. The resolution has, of course, been to favor Freund's broader approach, rather than the "pure law" that had been advanced by Dean Ames."

\section{THE LAW SCHOOL: 1934-1937}

In 1934, I became a beneficiary of the Law School's broad-gauged and rigorous approach to legal education. In the autumn of that year, I enrolled, as I have said, in the Law School's professional program. Life outside the Law School was grim: We were mired in the Great Depression; in 1933, the unemployment rate had reached almost 25 percent, and it declined only modestly in the next few years. The depres-

doubled to 27. Ellsworth, Law on the Midway at 125-26 (cited in note 1).

20 Charles Warren, 2 History of the Harvard Law School: And of Early Legal Conditions in America 476 (Da Capo reprint 1970) (originally published 1908) (quoting the Annual Report of the President for 1901-02).

21 Samuel Williston, The Law School, 1 Harvard Law School Bulletin No 2, 5 (July 1948) (elaborating on this idea in a short, essentially reminiscent piece).

22 There has, of course, been concern that undue preoccupation with "extra-legal" knowledge could compromise the cultivation of the more conventional insights, the rigor, and the precision of the challenging discipline of the law. For the problems involved, see Richard A. Posner, The Decline of Law as an Autonomous Discipline: 1962-1987, 100 Harv L Rev 761, 761 (1987) (arguing that, although "the autonomy of legal thought was [once] relatively secure,... [i]t is no longer," and describing the process that effected this transformation). Compare R.H. Coase, Law and Economics and A.W. Brian Simpson, 25 J Legal Stud 103, 103 (1996) ("Of course, there was Leonardo da Vinci-and there is Richard Posner-but no subject can flourish if it has to depend exclusively or even largely on such exceptionally well endowed individuals."). 
sion first rocked the foundations of our system and then reshaped them.

Events abroad were also gloomy. Hitler had acceded to power as Chancellor of Germany in 1933. Like most of our elders, the majority of my fellow students and I did not sense the full implications of this prelude to worldwide disaster. We did, however, get a better sense of the terrible effects of the Nazi system from German refugees who were members of our class. We also had to try to digest Hitler's denunciation of provisions of the Versailles Treaty, his remilitarization of the Rhineland in defiance of the treaty, and his later pact with Mussolini, Italy's fascist leader. But such large events were in general remote from our main concerns, which were focused on what we would have to face in the "old" law building.

I have learned that some of our younger alums believe that the "old" or "original" law building is Saarinen's magnificent glass-walled creation, south of the Midway, on 60th street, as it was before being transformed into a square by the addition of the annex in 1987. That belief is, however, grave error: The original building - the venue for the Class of 1937-was a gray Bedford Stone building located in the quadrangle west of University Avenue and south of 58th Street. It is now Business East, and I understand that the Graduate School of Business never paid the Law School for it, a precedent that the Business School now uncomfortably confronts as it prepares to move into its new quarters being built on Woodlawn Avenue.

Before turning to what was the main business, our legal education, in and out of the classroom, I want to mention several wondrous happenings in that building. First was the memorable encounter of our Dean, Harry A. Bigelow, with Bertrand Russell. Dean Bigelow was an urbane, nimble, versatile gentleman and scholar, a master of, inter alia, property law, criminal law, and conflict of laws. Lion hunting, and I am not speaking figuratively, was one of Dean Bigelow's hobbies. While dean, Mr. Bigelow also served as trustee in bankruptcy of Insull Utility Investments, whose bankruptcy in the 1930s was a famous local and national event. ${ }^{23}$

On the night in question, Miss Muir, the Dean's secretary and entire administrative staff, handed him (I assume) a resume about the evening's speaker. Bigelow had presumably rushed in from a downtown meeting in order to introduce the distinguished guest. He began by noting that Russell had been educated at St. Cyr (a famous military school), and had been decorated for gallantry at such and such battle, and so on. Russell, a prominent pacifist, finally interjected, "Sir, you

23 See Sheldon Tefft, Bigelow, Harry Augustus, in John A. Garraty and Edward T. James, eds, Dictionary of American Biography, Supplement Four 1946-1950 77, 77 (Scribner's 1974). 
are confusing me with my cousin." Our lion-hunting dean, whose only weapon was an irrelevant resume, knew how to cope with a crisis. He began all over again, and repeated every word he had said, but carefully inserted a "not" before every verb and then presented the speaker of the evening. Russell's talk is, alas, among the great mass of things I have forgotten, but I still remember, and marvel at, Dean Bigelow's cool and nimble recovery.

Another Bigelow story exemplifies how the Law School has - not for the last time - dealt with aberrant student behavior without calling on the cops. Our smoking lounge had become a gambling den. There has, of course, been a seismic cultural change. In the 1930s, gambling was considered more dangerous than smoking, at least by the state, which had made various forms of gambling illegal. So it was that an alumnus zealous about public policy telephoned Mr. Bigelow, and demanded that he call the police the next time the unlawful crap game, for example, was in full swing in our basement.

Bigelow showed his characteristic responsiveness to alumni complaints about minor forms of student misbehavior, as well as his diplomatic skills. First, he told Miss Muir that he had to get a book from the library and asked her to remind him on his return that he had to call the police to deal with any gambling going on in the lounge. Bigelow left just long enough for Miss Muir to do what was necessary! Although Miss Muir duly reminded Mr. Bigelow upon his return, his subsequent inspection showed that the gambling had melted away. Miss Muir had apparently atoned for the Russell miscue.

Bigelow, who embraced the rehabilitative ideal, did more: He put a ping-pong table in the lounge. Some of the gamblers, as a result, turned to ping-pong - at least during the day. The lounge apparently became too noisy for them to figure the odds. We even had a Law School ping-pong tournament, but there was no point-shaving at this institution.

I turn now to the interrelated core concerns of my classsurviving the first-year and beginning to learn how to become a lawyer. Many students, including those who had been academic stars in college, had apprehensions about survival: At the Law School the attrition rate was, I believe, substantial, but I can't be more precise about the number or percentage of first-year students who did not make it to the second year, or indeed did not graduate. ${ }^{24}$ It was easy to

24 Fixing the exact attrition rate is complicated by the following factors: 1) Many students went to summer school and graduated before the end of the third year after their enroliment; 2) There were transfer students; 3 ) We had a four-year program as well as a three-year program. Consequently an accurate determination of the attrition rate would require tracing the law school career of each student who entered with my class in 1934. I propose to leave that inquiry for the Law Review issue that presumably will celebrate our Bicentennial. 
get in but, I believe, harder than at present to get out - with a degree. I doubt, however, that our attrition rate approached that reflected in Professor Edward ("Bull") Warren's famous prophecy to the first-year students at the Harvard Law School: "Look to your left; look to your right; look at yourself; one of you three will not be here next year." Recently Professor Daniel Meltzer of the Harvard Law School has brought the Harvard situation up to date, saying this: "Look to your left; look to your right; look at yourself; one of you three will not graduate with honors." In the 1930 s, our own faculty naturally wanted to protect the community, as well as students themselves, from false credentialism. Presumably, the faculty was also concerned about depreciating a school's diploma by awarding it to students who seemed to lack the intellectual capacity or industry requisite for successful practice. Selective admissions have, for some time, avoided the obvious wastage of an earlier time.

My memory, faltering or rose-colored as it may be, is that for most of us, apprehension soon receded into the background for two reasons: First, the work was challenging, typically the most challenging academic experience of our lives. Second, many of us (albeit at different speeds) began to have a sense of our increasing ability to cope with the intellectual demands of the Socratic method, for which cases were, of course, a splendid instrument.

The Socratic method predominated in the classroom, especially during the first year. I am not going to expatiate here in the abstract on the power of that method, its limitations, or its recent decline. ${ }^{25} \mathrm{I}$ do want, however, to share my recollection of its impact on the Class of 1937. The method was, of course, used differently by different teachers and, indeed, by the same teachers. How it was used depended on various circumstances: the subject matter, or how far along we were in the class hour or in the quarter, or our growing capacity to "state the case" and to handle the inevitable questions. I remember particularly the mastery of the method by my first-year teachers: John Potts Barnes, Dean Bigelow, Charles Gregory, Ernst Puttkammer, Malcolm Sharp, and Sheldon Tefft. They kept the entire class engaged, albeit sometimes mystified. They varied in the ratio of declarative sentences to questions per class. But they all typically did not tip their hand as to when a student would be called on. The result usually was the collective engagement of the whole class, with the conversation between the teacher and a student.

If a question was put, we were all supposed to, and typically did, wrestle with it as it was asked. Prudence, as well as the continuous desire to gauge our capacities, inclined us to listen carefully to the stu- 
dent on the firing line. We might, after all, be asked to appraise aspects of his answer. We never knew when we would be on the spot. Finally, we learned a good deal from our professors' almost magical capacity to reformulate a student's question, which appeared to be elusively inchoate, into a clear and insightful query.

Naturally, we learned some basic black letter law. The Socratic method is a notoriously inefficient instrument for that end. But it had achieved more important purposes: giving us some experience in reducing a complex case or situation to its essentials; forcing us to examine the rationale for decision so as to determine what was essential and what was extraneous; making us dissect the internal logic of an opinion and its contribution vel non, to the social purpose it defined or implied in the opinion; and showing us how to explore a decision's fit with precedent as well as its implications for the future. In reaching for those goals, we were forced to recognize what we didn't know and what, if anything, we or others could do about it. At the same time, we had to, as best we could, extract the social purpose and effect of the decision. Throughout, we had to ask ourselves what could be said for the other side. We soon realized that we could not state our side well without grappling with that question. In short, we learned how to read, harmonize, distinguish, and evaluate cases - to argue from precedent.

The pervasive questioning of judicial opinions contributed to our willingness to question authorities. Most of our teachers made it clear that the power of an argument depended on its content, not its source, and most encouraged us to challenge their ideas as well as those of the courts and our fellow students. Arthur Goodhart (a distinguished professor of jurisprudence at Oxford) caught the spirit of our classes when he observed: "The English teacher [of law] emphasizes what the judge has said: the American professor explains what the judge should have said. ${ }^{, 26}$ The Great Depression may also have reinforced this skepticism about authority because it highlighted the weaknesses of our basic institutions.

The case method did not, of course, focus on other aspects of legal education, such as research, writing, drafting, trial practice, and negotiation. For most students, there wasn't much to supplement the diet of cases. Occasionally, in a large class, a teacher assigned a paper, but papers were usually required only in seminars, and we had only a few of them, unlike the rich options available to our students today. The establishment of the Bigelow Teaching Fellow program in the late 
1930s, of course, significantly expanded training in legal writing and research."

Members of our Law Review, founded in 1933, had a wonderful opportunity to do research and writing, to learn how to give and take criticism, and to integrate a suggestion into the basic structure of their work, rather than relegating it to a footnote. There was, of course, the added pleasure of seeing one's work in print, even though the Review did not then identify student authors of notes or comments. Although this anonymity has been ended here and at other schools, in the 1930s we did not question this practice. It reflected the collaboration that had gone into the final case note or comment. ${ }^{28}$

\section{The Class of 1937}

I want here to highlight other differences between the members of the Class of 1937 and the classes of the last few years.

In the '30s, there were many more commuters from their homes in Chicago. One obvious reason was the Great Depression and the resultant pressure on students to economize by living at home. Indeed, one of my commuting classmates nostalgically recalls his scholarship and his struggle for trolley fare to the College and Law School.

The Law School was, of course, much less diverse in other ways that reflected the bigotries and interrelated job norms of the time. Our class had only a sprinkling of women and minorities - not because of any discrimination by the Law School but because of the constraining norms of that period. Since then, the civil rights revolution has, of course, shattered many, albeit not all, structures of discrimination, including those in some law firms and universities. Incidentally, the transformative opening up of our profession in the last fifty years is often neglected in the ballooning literature of disenchantment about some aspects of contemporary law practice. The erosion of invidious barriers has naturally made law a more attractive option for women and minorities, once largely excluded from important segments of the profession.

I have digressed a bit from looking at the distant past, and I now want to return to my classmates. We were, on the whole, quite serious about our work, especially during the first year. Generally, as I already said, we were short of money; we didn't have cars or TV. Although prohibition had ended in 1933, the culture it imposed was still influen-

27 One of the earlier Bigelows was the late Max ("Moose") Isenbergh, the father of my colleague, Joseph Isenbergh, whose Essay entitled Activists Vote Twice appears on page 159.

28 Changes after the 1930s in the Law Review eligibility standards have expanded the size and the proportion of Law Review staff. Furthermore, new journals and changes in Law School requirements for graduation have expanded student research and writing. I cannot spell out those developments here. 
tial. I don't remember any large group that tried to make up for lost drinking opportunities. To be sure, I was hanging out with the Law Review and the work preempted drinking time. As I have said, there was some gambling in "the smoking lounge" until Dean Bigelow brought in the ping-pong table. But my recollections, which are admittedly shaky and perhaps reformed with time, are that we were pretty sober and serious, but not a stodgy lot.

The general bleakness was relieved a bit by the students' helpfulness to each other. I was not aware of any of the intra-student beastliness, portrayed in films such as "The Paper Chase." Quite the reverse: Study groups often took in students experiencing academic difficulty. One group, for example, included a student who happily was destined for the family business. The property course was his nemesis. But his group was committed to overcoming that obstacle. Alas, the group failed-more than once. He was reexamined in property, a required course, twice more and failed twice more. He ultimately received his law degree from a local night school, passed the Illinois bar exam, and got his license. With colorful language, he asked a fellow student to advise (and startle) the property teacher of that news. This new member of the bar wisely did not use his license to practice law, but only as a testament to the intransigence (as he saw it) of his property teacher.

Student-faculty relations then were more formal than they are today. We did not expect to break bread with our teachers. Those were heights few of us aspired to scale. Nonetheless, members of the faculty were quite helpful. They would tell us about jobs that seemed suitable for particular students, write letters of recommendation, and act generally as mentors.

Such faculty support was especially important, not only because jobs were scarce, but also because the Law School's administrative resources were thin. The school, like its peers, had no placement office. Good shoes and a stout heart were important placement tools. Students pounded pavements, going to law offices, instead of the offices coming to school. Occasionally, a professor would, as I said, come up with an opening, but such openings were hard to find. In any event, we did not think that it was the school's responsibility to see that we were placed. The school's responsibility was to see to it that we could do our job when and if we got one. Similarly, it was not the school's province to see that we were happy campers; there was no assistant dean to help with particular problems or to serve as a bridge between students and faculty. The school's concern was with the development of

29 Students would phone from the library desk for an appointment rather than knocking on an open faculty door, as they now do. We might ask to see a professor to discuss a personal problem, or to question a statement in a book he had written. Generally we stuck to legal business. 
our minds and character. It may have overdone the Spartan ethos. In any event, my purpose here is historical rather than a hankering for the "good old days."

I have indulged in over-simplification by failing to highlight the varying amounts of credit my fellow students had earned in previous academic work. Some students already had at least an A.B. or a similar degree that presupposed four years of college credit. A good many others chose (as I did) the "professional option," coming to the Law School from the University of Chicago College after credit for only three years of undergraduate work. If such students did "satisfactory work" in their first year of law school, they would get their college degree, as well as credit for their law degree. Finally, a third and relatively small group consisted of students admitted after only two years in the College. Their work here consisted of a pre-professional year, equivalent to the third year of college, which could not be counted toward the professional degree. The prescribed courses for that preprofessional year were broad in scope and diverse in methodology. The Law School's acceptance of responsibility for the third year of college harked back, you will recall, to one of Freund's "heretical" suggestions.

The pre-professional program in the 1930s was, however, essentially a sideshow. The main business was, of course, the professional program. Professor Freund remained on our faculty until 1933, but his influence naturally extended well beyond that time. Administrative Law was an integral part of the curriculum, taught by Professor Sears, who also was a close student of reforms in judicial selection. Similarly, accounting for lawyers was an integral part of the corporation course, taught by Professor Wilber G. Katz. Other courses that Freund had proposed included Trade Regulations (the law of competition); $\mathrm{Mu}$ nicipal Corporations; Comparative Law, taught by Professor Max Rheinstein, who had left Germany in 1933 and who later held the first chair in comparative law in the Law School; International Law, taught by political scientist Quincy Wright; Legal Sociology, and Philosophy of Law; and Constitutional Law and Constitutional History, a course with a controversial thesis taught by Professor William Crosskey. ${ }^{31}$ But

30 See The Law School, 1934-35, 34 Announcements: The University of Chicago No 2, 5-6 (June 10,1934). For a description of the pre-professional year by one of its architects and teachers, see Mortimer J. Adler, Reflection on the Law School in the '30's, The Law Alumni Journal 37, 37-40 (Fall 1977).

31 Crosskey was the author of a controversial work entitled Politics and the Constitution in the History of the United States (Chicago 1953). He rejected the traditional restrictive view of the Commerce Clause and urged that "commerce among the states" comprised all commercial activities including manufacturing and agriculture, activities that had been held to be beyond the reach of national authority under the Commerce Clause. See id at 83 . The reviews of his work sharply disagreed. Strongly unfavorable reviews include Henry M. Hart, Jr., Professor Crosskey 
even more significant than the range of courses and teachers was the explicit recognition throughout the curriculum that law had social purposes and effects that were illuminated by the relevant insights of other disciplines. That approach was, of course, to be deepened and broadened in the post-war period.

\section{WORLD WAR II AND ITS AFTERMATH}

War obviously diverts potential law students and faculty to sterner tasks. Thus, the Law School (as did other schools) experienced a sharp decline in enrollment during both World Wars. ${ }^{32}$ In World War II, a significant part of its faculty temporarily left the school for warrelated work, and a substantial part of the law building was used by the Army and Navy. They used the first and third floors of the building, while the regular work of the school was carried on in the basement. ${ }^{33}$ This space allocation was obviously a mark of the needs and priorities of that devastating period.

By all accounts, Wilber Katz, who had succeeded Harry Bigelow as Dean in 1940, handled the difficulties of the early years of his deanship with great skill. After Dean Katz took leave in 1942 to work for Army ordnance, Sheldon Tefft, as Acting Dean, also served the school superbly. Wilber Katz resumed his deanship in 1945, and led the process of reinvigoration and rebuilding. Edward Levi also returned from his work in the Antitrust and War Divisions of the Justice Department. Because he and Wilber shared seminal ideas about legal education, and were close and mutually admiring friends, it is likely that Edward played a significant role in the steps taken soon after the end of the war.

By 1946, Walter Blum, Harry Kalven, William R. ("Bob") Ming, and Richard Watt had been recruited for the faculty, adding to the strength and vitality of the school. Incidentally, Bob Ming was the first African-American appointed to the faculty of a major American law school. I, too, came aboard in 1946.

At first glance, these post-war recruits appeared to be ingrown, all having been products of the Law School. But this appearance was mis-

and Judicial Review, 67 Harv L Rev 1456, 1486 (1954); Julius Goebel, Jr., Ex Parte Clio, 54 Colum L Rev 450, 451 (1954). Favorable reviews include Charles E. Clark, Professor Crosskey and the Brooding Omnipresence of Erie-Tompkins, 21 U Chi L Rev 24, 24 (1953); Walton H. Hamilton, The Constitution-Apropos of Crosskey, 21 U Chi L Rev 79, 91-92 (1953). See also William Winslow Crosskey and William Jeffrey, Jr., 3 Politics and the Constitution in the History of the United States: The Political Background of the Federal Convention (Chicago 1980). The relevance of Crosskey's views has been undercut by the Supreme Court's post-1937 Commerce Clause jurisprudence.

32 See Dennis Hutchinson, Elements of Law, 70 U Chi L Rev 141, 148-49 (2003).

33 See A Report by Dean Wilber G. Katz, The University of Chicago: The Law School 1942-1947 1 (Jan 2, 1948). 
leading. They had had quite diverse experiences, in private practice, the federal government, in the Army and Navy, and in society. For example, I had spent a year as a graduate student at Harvard Law School immediately after my graduation from the University of Chicago Law School. In addition, Edward Levi had spent a graduate year as a Sterling Fellow at Yale Law School. His academic experience had, moreover, been enriched by the reality test of his wartime work in the Department of Justice. Thus, these younger members of the faculty brought diverse experiences and legal perspectives to the faculty.

The faculty was hospitable but careful about adopting new courses. It was careful because the faculty was small. Furthermore, because there was, as always, so much ground to cover, the faculty wished to avoid unprofitable duplication, as well as truncated and incomplete "courses," which generated such duplication. More could be less, of course, absent the care taken to avoid unintegrated proliferation. This approach resulted from self-regulation and a sense of institutional responsibility, rather than any bureaucratic regulation. Consequently, there was no sense of interference with respect to new initiatives on the part of individual faculty members. Indeed, one reason for this attitude was the war. Its agonies and atrocities had heightened questions about the idea and nature of law. ${ }^{34}$ Furthermore, new postwar institutions invited a review of the agenda of legal education. For instance, a new course that I gave in 1947 dealt with the Charter of the United Nations, and specialized agencies, such as the International Monetary Fund and UNESCO. Colleagues from the philosophy and economics departments participated in teaching this course. These guests, incidentally, remarked on the vigor and quality of student dialogue.

There were also more local stimuli for review and reappraisal of the goals and methods of legal education and research. During the 1930 s, the University of Chicago had been wracked by internal controversies. These included the appropriate curriculum for the College, its autonomy, the relationship between "facts" and "ideas," and the relative roles for philosophy and science. Much of this debate was elusively abstract, at least to me, and seemed to invite passionate controversy that slighted the undisputed interdependence between "facts" and "ideas." Robert Maynard Hutchins, the young, charismatic, and articulate President of the University of Chicago, was at the center of this controversy, and indeed seemed to lead the charge in support of

34 See the famous debate between Hart and Fuller: H.L.A. Hart, Positivism and the Separation of Law and Morals, 71 Harv L Rev 593 (1958); Lon L. Fuller, Positivism and Fidelity to Law-A Reply to Professor Hart, 71 Harv L Rev 630 (1958) (debating, in the shadow of World War II, whether there is a distinction between law and morality). 
the primacy of the humanities and philosophy over science, particularly over social science.

The ferment about educational goals and methods, and the autonomy of, and the relationships among, different disciplines, presumably heightened the Law School's perennial concern about the curriculum: In particular, the so-called "Hutchins College" may have been a catalyst for the Law School's four-year program. The general education curriculum of the College had been designed for students who had finished their first two years of high school, and who would spend two more years in the College, and who could then be awarded an A.B. degree. Plainly, the Law School's four-year program, described by Wilber Katz in a 1937 article, ${ }^{36}$ would be a nice fit for graduates of Hutchins's College.

In that article, Katz described a program for effective integration of law and other disciplines. I won't assume the risk of summarizing his proposed program. But it is worth noting that he had highlighted a central element of the school's post-war agenda, as well as its entire history, stating that "the most striking feature of our plan is in the incorporation of subjects such as economics, political theory, and psychology." ${ }^{37}$ Katz naturally recognized that the integration of law and the social sciences had long been a staple of law school publications, but he also observed that there had been more fanfare than progress in that approach.

The Law School's new four-year program had a relatively short life. It was formally ended in 1951, on the ground that experience indicated how the program's goals could be achieved in a regular threeyear program. ${ }^{39}$ Furthermore, faculty whose work and interest dovetailed with the terminated program continued to have a significant influence on their colleagues' scholarship and teaching. For instance, the existence of that program had presumably been a factor in the ap-

35 See, for example, Robert Maynard Hutchins, The Higher Learning in America (Yale 1936) (describing the confusions and disarray in higher education, reflecting ambivalence about empirical work, and emphasizing the importance of the great classics and of "first principles" and metaphysics). For a penetrating criticism of Hutchins's views, a demonstration that they had not been accepted by his own University, as well as a fervid concern about Hutchins's authoritarianism, see Harry D. Gideonse, The Higher Learning in a Democracy 5-10 (Farrar \& Rinehart 1937). For a discussion of the hostile reactions to Hutchins's approach within the University, and the rise and fall of the so-called "Hutchins College," see John W. Boyer, Three Views of Continuity \& Change at the University of Chicago 47-68 (Chicago 1999). (1937).

36 See Wilber G. Katz, A Four-Year Program for Legal Education, 4 U Chi L Rev 527, 527

37 Id.

38 See id at 528 (discussing attempts to integrate interdependent fields and reasons for lack of progress).

39 For more information about the four-year program, see The University of Chicago: The Law School, 1949-1950, 49 Announcements: The University of Chicago No 10, 3 (July 5, 1949). 
pointment in 1942 of Henry C. Simons to the law faculty. Simons was a provocative and talented economist whose work broadened the perspectives of his colleagues. ${ }^{40}$ As a testament to his influence, Charles Gregory and Harold Katz included Simons's provocative essay, "Some Reflections on Syndicalism," in their labor law casebook, published in 1948. This essay raised the question of the costs imposed on the consumer, other workers, and society, by powerful labor unions. At the same time, Simons recognized the positive contribution unions could make. Students and teachers who read this essay could scarcely continue to oversimplify labor relations as a contest implicating only capitalists and workers. Rather, they had to consider how to achieve the benefits of unionization without undue social costs.

A few years after Simons's appointment, the famous interdisciplinary collaboration between Edward Levi and Aaron Director (another tough-minded and provocative economist) began. They cotaught the Antitrust course, which obviously implicated the insights of economics. The memorable Levi-Director collaboration was a natural outgrowth of the goals and methods of the four-year program. Levi and Director systematically explored the relationship, and especially the tension between the doctrines of antitrust law and economics. Although other colleagues had brought economics and other disciplines to bear on their teaching and scholarship, the Levi-Director effort was more sustained, systematic, and influential. ${ }^{42}$

At a retirement dinner for Edward Levi (as well as for Phil Neal and me), Robert Bork, a student in the Levi-Director class, described it as something like this: Edward explained the law, and Aaron then demonstrated that the law was dead wrong. Bork added that Edward taught him the essence of oral argument: For after the two men debated in class, and Director proved with inexorable logic that the law was nonsense, Levi switched to making fun of Director's mustache.

Interdisciplinary scholarship like the Levi-Director collaboration led to the establishment in 1958 of The Journal of Law and Economics. The Journal achieved distinction by publishing and encouraging distinguished articles that illuminated the workings of our legal system, and also showed its effects on our economic system. The sustained and systematic collaboration of Edward Levi and Aaron Direc-

40 For an appreciation of Simons's work and a collection of his essays, see generally Henry C. Simons, Economic Policy for a Free Society (Chicago 1948) (Aaron Director, ed).

41 See Charles O. Gregory and Harold A. Katz, eds, Labor Law: Cases, Materials and Comments 1086 (Michie 1948).

42 For a description of the background, the personnel, and the accomplishments of the Law and Economics Program, see Edward H. Levi memorandum of August 3, 1955, 8-9, enclosed with his letter of August 3, 1955 to H. Rowan Gaithen, Jr., President of the Ford Foundation (Edward H. Levi Collection, University of Chicago Library). 
tor, along with the Journal and the contributions of other members of our faculty, set the stage for the development of the law and economics movement, now such a pervasive and powerful force, in our law school and throughout the world.

In 1950 Edward Levi became Dean of the Law School. An aspect of his appointment is worth mentioning as a mark of our national progress. When President Hutchins proposed Edward's appointment, some members of the Board of Trustees demurred to appointing a Jew as Dean of the Law School. ${ }^{43}$ Hutchins, a vigorous opponent of bigotry of any kind, threatened to resign if that view prevailed. Edward was then appointed Dean, to "the great benefit of the Law School, the University, and the United States," as Edward Shils wisely observed."

Like his predecessor, Wilber Katz, Edward asked searching questions about the strengths and shortcomings of legal education. One result was the collection of his superb "4 Talks on Legal Education," published in $1952 .{ }^{45}$ His talks were subtle and elusive and not easily summarized, but a central theme of these talks was clear and compelling: The insights of the social sciences and the humanities properly integrated with law would not only improve legal education, but would also illuminate the operation of legal institutions ${ }^{46}$ and promote social welfare.

In submissions to the Ford Foundation, beginning in 1952, Edward persuasively stated the case for a program in Law and the Behavioral Sciences. Such a program, he urged, would promote the advancement of the behavioral sciences, as well as understanding of the law. The Foundation responded with generous support for such a program and later for other initiatives, mentioned below.

The initial projects selected by the Law School for interdisciplinary study were the American jury system (the Jury Project ${ }^{47}$ ), commercial arbitration (the Arbitration Project ${ }^{48}$ ), and a study of attitudes concerning the distribution of tax burdens, particularly the federal income tax, and the linkage between such attitudes and public policy under a system whose effectiveness depended primarily on self-

43 See Edward Shils, Robert Maynard Hutchins, in Edward Shils, ed, Remembering the University of Chicago: Teachers, Scientists and Scholars 185, 195 (Chicago 1991).

44 See id. See also In Memoriam: Edward H. Levi (1912-2000), 67 U Chi L Rev 967 (2000) (collecting addresses by, among others, former University of Chicago President Hugo F. Sonnenschein and former U.S. President Gerald R. Ford).

45 Edward H. Levi, 4 Talks on Legal Education (University of Chicago Law School 1952).

46 See id at $41-51$.

47 For elements of the Jury Project, see Harry Kalven, Jr. and Hans Zeisel, The American Jury v (Little, Brown 1966).

48 For elements of the Arbitration Project, see Soia Mentschikoff, The Significance of Arbitration-A Preliminary Inquiry, 17 L \& Contemp Probs 698, 699 (1952). 
reporting, or as Mr. Justice Jackson put it, "taxation by confession.", I won't try to describe these projects in detail, but I do want to add a word about the Jury Project because I had a role in its development and have a clearer recollection of it, ${ }^{50}$ and because it was the best known and most productive of the projects in Law and Behavioral Science.

One aspect of the Jury Project attracted unwanted attention and generated considerable commentary, most of it critical. This commentary did not deal with the basic contributions of the study. Nonetheless, it is worth mentioning because it reflects the perils that appear to intrude on the privacy of our basic institution.

The criticism resulted from the public disclosure that the staff of the project had taped jury deliberations in selected civil cases. The taping had been approved by the U.S. District Court in Wichita, Kansas, and the Court of Appeals for the Tenth Circuit, and consented to by the lawyers and the parties in those cases. In order to avoid affecting the jurors' behavior, they were not told about the taping. The jurors' privacy was protected by masking the names of the cases, the lawyers, and the locale of the trial court.

In 1955, the judges of the Tenth Circuit decided that an edited version of the tapes should be played at their annual meeting. Ed Levi had strongly opposed that idea and explicitly sought to disavow any connection of the Law School with the proposed presentation. He could not, however, hold back the judicial tide. On July 7, 1955, the edited record was played in Estes Park, Colorado. As I have said, a storm of criticism erupted that overwhelmed the few defenders of the taping. The defenders emphasized the scientific purposes and the protections of privacy built into the arrangement, as well as the prior judicial approval. Senate hearings and a condemnatory committee report led ultimately to a federal statute that made the taping of jury deliberations in a federal court, with or without consent of the jury, a federal crime. Once again, the Law School, albeit inadvertently, had made law.

49 United States $v$ Kahriger, 345 US 22, 36 (1952). For a report on the progress of the Law and Behavioral Science Program, including the Jury Project, the Arbitration Project, and the Taxation Project, see Edward H. Levi, Law and Behavioral Science Program: University of Chicago Law School, December 21, 1954 (Edward H. Levi Collection, University of Chicago Library). The Tax Project was ultimately abandoned on the ground that the issues involved were too complicated to be illuminated by the questionnaires that had been expected to be the basic techniques for the project.

50 For a description of the project in its developmental stage, see Bernard D. Meltzer, $A$ Projected Study of the Jury as a Working Institution, 287 Annals of Am Acad of Polit \& Soc Sci 97 (1953). I was the architect and first director of the jury project, followed by Philip Kurland and Harry Kalven.

51 Act of Aug 2, 1956, 70 Stat 935, codified as amended at 18 USC $\$ 1508$ (2000). 
The operations of the Jury Project and other elements of the Program in Law and Behavioral Sciences had led to the conversion of library space and seminar rooms into offices for the required personnel. The presence of psychologists and sociologists in close proximity to lawyers promoted the interdisciplinary cooperation that was at the heart of the program. Accordingly, Edward Levi asked the Ford Foundation for help in constructing a new building. The Foundation did make a supplemental grant to the Law School, which helped make the new law building possible.

Before turning to the new building, I want to say a word about some of the other initiatives that were made possible by grants from the Ford Foundation. The British Commonwealth Fellow program, another new program of the 1950s, enrolled recent law graduates from the United Kingdom and the British Commonwealth countries for a year of study at Chicago. However, rather than undertaking work tailored for graduate students, the Fellows enrolled in the classes and seminars of our regular J.D. program and earned a Chicago J.D. by successfully completing a year of work here. They obviously learned about American law as well as our teaching methods, which usually differed substantially from those of their own country. They also, of course, interacted with our American students, and the crossfertilization broadened the perspective of both groups.

The participants in the British Commonwealth program generally expressed great satisfaction with it. Some of the fellows did, however, express their disappointment at receiving our first law degree (a J.D.) rather than a graduate degree. Although this disappointment may have been influenced by their aspirations for an academic career, many of them became teachers in the United Kingdom and throughout the commonwealth world.

The Foreign Law Program, also initiated in the 1950s, was a counterpart of the British Commonwealth Fellow Program, providing opportunities for American students to study abroad. Professor Max Rheinstein, the guiding hand of that program, also taught American law to foreign law students studying at the University of Chicago. The Foreign Law Program was designed to educate American law school graduates about the private law systems of France and Germany, which had served as the models for many other legal systems throughout the world. The program enabled a select group of American law students to deepen their understanding of foreign legal systems and cultures, and equipped them for more effective roles in the expansion of worldwide trade.

During the first year of that two-year program, a good part of the students' work was devoted to the intense study of the private law of either France or Germany (emphasized in alternate years). Distin- 
guished scholars from those countries, among others, would come to the Law School in order to work with Professor Rheinstein. The rest of the students' first year was devoted to work in the area of the students' specialized interests or in the area of international finance or trade. The second year took the students abroad, where, with the guidance of a mentor arranged by Professor Rheinstein, the student developed a course of study in a foreign university, often supplemented by work in a law firm, governmental office, or foreign business. ${ }^{52}$ After Professor Rheinstein became emeritus in $1968,{ }^{53}$ the emphasis changed to bringing more foreign students here for graduate work rather than sending American students to study abroad.

These foreign law initiatives did not, of course, distract Dean Levi from interrelated goals closer to home: first, to increase the quality and diversity of our student body and second, to strengthen our faculty. Accordingly, he instituted National Honor Scholarships under which a group of colleges and universities selected recipients for full scholarships to the Law School. He also took the lead in recruiting great teachers and scholars from other institutions. I will mention those that come to mind, even at the risk of unjustifiable omissions: Francis Allen, Brainerd Currie, Kenneth C. Davis, Allison Dunham, Nicholas deB. Katzenbach, Philip B. Kurland, Karl N. Llewellyn, and Soia Mentschikoff. Edward also helped attract some of our own promising graduates, including Kenneth Dam, Dallin Oaks, and Roger Crampton. Both groups of names will presumably evoke fond memories for our alumni, among other readers. Not all of those listed lived out their academic years here, but they enhanced our teaching and scholarship, and presumably their own because of Chicago's influential interdisciplinary and rigorous culture.

In the fifties, the Law School created a variety of new opportunities for our students. For instance, the first-year class was divided into groups of eight or ten, with a faculty advisor for each group. Although individual members of the faculty had generally been accessible, the advisory system encouraged the more reticent student to ask for advice. It also gave the faculty a better sense of student concerns, needs, and aspirations. In addition, that system typically provided students

52 See Edward H. Levi, First Annual Report to the Ford Foundation on the Program in International Organization and Law, October 16, 1962 (Edward H. Levi Collection, University of Chicago Library), for a description of projects under this program including Africa's new and emerging nations. See also David P. Currie, ed, Federalism and the New Nations of Africa (Chicago 1964) (comprising papers presented at a Law School symposium).

53 For an appreciation of Max Rheinstein by one of his American students in the Foreign Law program, see Mary Ann Glendon, Max Rheinstein, 45 U Chi L Rev 516 (1978). Professor Glendon's article is one of a series in a memorial edition of the Law Review celebrating Rheinstein's formidable learning and prodigious accomplishments. 
with the hospitality of home-cooked dinners, which students recalled with pleasure many years later. ${ }^{54}$

During the same period, the Law School established a placement office. James Ratcliffe, J.D., became Director of Placement and Alumni Relations. Furthermore, Jo Desha Lucas, after one quarter as a superb Bigelow Teaching Fellow, became Dean of Students, looking after admissions, financial aid, and student problems and grievances in general.

In addition, in 1957, the Mandel Legal Aid Clinic was established on the premises of the school. The Clinic gave students not only an opportunity to test and deepen their knowledge through experience but also appreciate the pleasure of, and the responsibility for, service to others. The 1950s thus saw the creation of most of the core elements of the necessary administrative support for the Dean, faculty, and students.

These initiatives and others in the planning stage made it clear that the original Law School building could no longer meet our needs. It didn't have enough space for student activities, or for a larger faculty and a larger library; the building was, in general, obsolete. Because of its leaky roof, the results of some laborious research had been literally washed away. And of course, the building lacked air conditioning and was oppressively hot during our summer sessions. (A summer session had been a staple of the Law School from its inception and continued until approximately 1967.) Indeed, Edward Levi, in a submission to the Ford Foundation, observed that the University of Chicago Law School had the worst physical facilities of any major American law school. ${ }^{55}$

Furthermore, Dean Levi, bless his heart, was particularly concerned about the lack of office space for emeritus professors, such as George Bogert and Ernst Puttkammer. After considering feasible options, we decided to build across the Midway on 60th street. We had reason to expect that our relationships with other parts of the University were close enough to survive the ten-minute walk to the center of campus. It was Edward Levi's vision and energy, together with the generous support of the Ford Foundation, our alumni, and friends, that made the new structure possible. The students had good reason for

54 The advisory system has been superseded by other arrangements designed to provide both advice to students and greater opportunities for informal student-faculty relations. These arrangements include a full-time dean of students, smaller classes, more seminars, informal coffees and lunches for students and faculty, and a great increase in the faculty use of research assistants. Finally, the layout of the Green Lounge and its adjacent café promote informal and spontaneous student-faculty relations. But 1 must, however, confess to a strong, if possibly out-of-date, affection for that advisory system.

55 See Edward H. Levi memorandum at 16 (cited in note 42). 
naming the reflecting pool in front of the main building "Loch Levi." (Antoine Pevsner's striking bronze sculpture, "Construction in Space in the Third and Fourth Dimension," a gift of alumnus Alex L. Hillman, J.D., 1924, dominates Loch Levi. In the late 1990s the Pevsner sculpture was restored to its original color through the generosity of Mark and Anna Siegler in memory of their meeting next to the uncrated, unmounted sculpture.) Edward's basic conception was a set of facilities that would promote fruitful interplay of the Law School with the bench, the bar, and scholars in disciplines relevant to the law. Indeed, our next-door neighbor to the east was to be the American Bar Center, which housed the American Bar Foundation, the ABA's research unit. A courtroom would provide a dignified and modern facility for student moot court programs, or even for real trials. An auditorium would seat all of our students and accommodate large conferences and similar events.

A series of special events celebrated both the architectural magnificence of the new building and the high aspirations that had led to its creation. The participants included Chief Justice Earl Warren and the Lord High Chancellor of Great Britain, Viscount Kilmuir, both of whom spoke at the cornerstone laying on May 28, 1958. VicePresident Nixon was the primary speaker at the first dedication of the new building on October 5,1959. On the next day, the law faculty held its first classes in the new building, thereby achieving the primary purpose of the vision and energy that had produced the new structure. There was also a special convocation on May 1,1960, where honorary degrees were conferred on eminent jurists from the U.S. and abroad, as well as on the Secretary-General of the United Nations. ${ }^{56}$ Governor Nelson Rockefeller, grandson of our founding benefactor, was the principal speaker at that convocation.

Many other events reflected the links between the Law School, the bar, and the judiciary, including an argument of a real case before the Illinois Supreme Court in our new courtroom. The Law School understandably did not stint on the celebrations. Although not directly connected with the new building, there was another occasion for celebration in 1960, the establishment of The Supreme Court Review, with Philip B. Kurland as its editor. This faculty-run review achieved distinction by encouraging and publishing penetrating discussions, by

56 Seven dignitaries received honorary degrees: Hon. Charles E. Clark, Chief Judge, U.S. Court of Appeals for the Second Circuit; Hon. Herbert F. Goodrich, Judge, U.S. Court of Appeals for the Third Circuit; Hon. Walter Schaefer, Associate Justice, Illinois Supreme Court; Hon. Roger Traynor, Associate Justice, California Supreme Court; Hon. Dag Hammarskjold, Secretary-General of the United Nations; Rt. Hon. Viscount Kilmuir of Creich, Lord High Chancellor of Great Britain; Hon. Earl Warren, Chief Justice, U.S. Supreme Court. 
scholars at Chicago and elsewhere, of the work of the United States Supreme Court.

The new facilities were put to good use. The courtroom was used not only for moot court, but also for real jury cases brought here by cooperating state court judges and with the consent of the lawyers involved. Similarly, the Illinois Supreme Court continued to bring into our courtroom arguments in real cases selected for their educational potential.

During the celebrations from April 28 to May 1, 1960, the courtroom was named for and dedicated to Weymouth Kirkland, a distinguished trial lawyer and advocate of free speech, whose generous colleagues at the law firm of Kirkland \& Ellis, and friends had supported the building of the courtroom. I must mention two other dedications, even though they occurred beyond my timeline here. They honored two of our distinguished alumni, Laird Bell, J.D., 1907; and Glen A. Lloyd, J.D., 1923. Their vision, energy, and generosity were indispensable for the creation of our new facilities.

On October 12,1966, the Law School's quadrangle was dedicated posthumously to the memory of, and named for, Laird Bell; University of Chicago former President Robert Maynard Hutchins spoke at the dedication. ${ }^{\text {s8 }}$ On May 3, 1976, the auditorium was dedicated posthumously to the memory of, and named for, Glen A. Lloyd; Chief Justice Warren Burger and Associate Justice of the Illinois Supreme Court Walter Schaefer spoke at the dedication. ${ }^{59}$

Bell and Lloyd had been partners in the eminent law firm Bell, Boyd, Lloyd, Haddad, and Burns. They had shared important values. Their lives had been a strong reflection of the idea later voiced by Edward Levi, that the well-trained and well-endowed had special responsibilities. As lawyers, they had earned esteem for their responsible craftsmanship, including their unswerving fidelity to the idea that the law was a public calling. They also served the wider community through their extraordinary leadership and generosity. In particular, the Law School and the University of Chicago had reason to be profoundly grateful for their distinguished service and their generous support for the University's expanding possibilities. They each had served the University as a trustee and then as Chairman of the Board

57 As those who worked out the arrangements for real cases left their posts, and as the Law School's courses and seminars in trial practice expanded, these uses of the courtroom faded away.

58 His presentation appears in 15 The Law School Record No 1, 1-5 (Winter 1967). See also Memorial in 14 The Law School Record No 1, 7 (Winter 1966), as well as resolutions by the Law School faculty (praising Laird Bell's service to the Law School) and Board of Trustees (same) on file at the D'Angelo Law Library of the University of Chicago Law School.

59 See Dedication of the Glen Lloyd Auditorium, 22 U Chi L Sch Rec No 1, 36 (Fall 1976). 
of Trustees. They gave the University wise counsel in difficult times. As Robert Maynard Hutchins said at the dedication of the Laird Bell Quadrangle, Laird Bell had defended academic freedom when it was not popular. Similarly, Glen A. Lloyd had honored and reinforced that idea. All these and many other specifics of their impressive accomplishments were widely recognized and acclaimed. It is enough to say here that it was natural that the Law School and University honored their memories. What is also clear is that the Law School honored itself by weaving their names more tightly into the fabric of its history.

I want to now go backwards in time and say something about our students immediately after World War II ended, when I joined the faculty. Many of our students were, of course, ex-G.I.'s, enrolling with the help of the G.I. Bill of Rights. They were generally older than typical first-year students. They had been matured by their military service. They were eager to make up for lost time. I have not had a more committed and interesting group of students. They were also extraordinarily sympathetic with, and helpful to, young teachers (like me) who were trying to learn subjects while teaching them.

The alumni were also hospitable and encouraging but they carefully, if discretely, reminded the neophyte teachers, in particular, of the tradition of excellence that we had inherited from our original faculty and their successors. One mantra was "Mechem Hall and Freund," spoken with the reverence appropriate for a golden age. That mantra, which I had first heard as a student, I heard again soon after I joined the faculty. The alums presumably sought not only to remind us of the tradition of excellence initiated by our first faculty, but also perhaps to keep our humility in order. Over the years, the names have changed but the reverence has not.

In our more recent past, it has been our great good fortune that our deans have maintained the energy and vision of past deans I have known: Bigelow, Katz, and Levi. Their successors collectively exemplify the grand professional and intellectual traditions of which I have spoken. Phil Neal and later, Geof Stone, are both superb legal craftsmen and public lawyers with a broad understanding of the intersection of law and government. Gerhard Casper and Norval Morris each brought to the school expertise not only in legal systems abroad, in which they were trained, but interdisciplinary commitments to political science and criminology, respectively. Our most recent deans, Douglas Baird, Daniel Fischel, and currently, Saul Levmore, all reflect, in quite different ways, the integration of economic analysis into the exploration of legal questions. All of these deans, too, have served the school with devotion and have, by their leadership and their contributions, further vitalized our intellectual tradition. But my focus here has 
been primarily on the older history, less well known to those who graduated when any one of these more recent deans were in office.

To avoid taxing the reader, I will leave to the future-perhaps to a memoir written for our bicentennial-a full account of their achievements. But one thing may be said even now: Given the distinctive strengths of our present faculty, our University, our students, alumni, and friends, the prospects are bright indeed that our second century will honor and reinforce the tradition of excellence that we are now celebrating. 


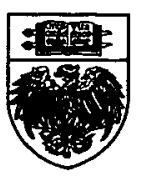

